\title{
Situation analysis of water quality in the Umtata River catchment
}

\author{
OS Fatoki ${ }^{*}$, NYO Muyima ${ }^{2}$ and N Lujiza $^{1}$ \\ ${ }_{1}$ Department of Chemistry, University of Fort Hare, Alice 5700, South Africa \\ 1 Department of Biochemistry and Microbiology, University of Fort Hare, Alice 5700, South Africa
}

\begin{abstract}
The Umtata River was characterised by using standard physico-chemical and microbiological methods to assess the present water quality in the river. The results indicated high turbidity, gross microbiological and cadmium pollution. Turbidity values ranged from 0.28 NTU to 1899 NTU highlighting the known problem of donga erosion in the catchment. Faecal coliform counts varied between 0 and 21000 counts $/ 100 \mathrm{~m} \ell$ while the total coliform counts ranged from 0 to 69000 counts for all the sites sampled. The levels of cadmium varied between $0.01 \mathrm{mg} / \ell$ and $1.0 \mathrm{mg} / \ell$. Nutrient levels were also high. Nitrate values ranged from $0.01 \mathrm{mg} / \ell$ to $28.0 \mathrm{mg} / \ell$ as $\mathrm{N}$ while phosphate values varied between $0.02 \mathrm{mg} / \ell$ and $5.0 \mathrm{mg} / \ell$ as $P$. The high coliform counts and the nutrient values exceeding acceptable limits are indicative of pollution from domestic wastes from several informal settlements located along the riverbank. Water uses in the area were determined and were found to be mainly domestic and recreational. The gross pollution of the river exposes the local people who depend on it for their primary water source to serious health risk. Another use included livestock watering.
\end{abstract}

\section{Introduction}

Water resource management in South Africa is going through a period of major change. This is reflected in two new acts, the Water Services Act of 1997 (Act No. 108 of 1997) and the National Water Act (Act No 36 of 1998). The acts are founded on the principles of efficient service delivery and sustainable use of water resources. Resource quality monitoring, assessment and a national information system in support of decision-making are primary requirements of both acts.

South Africa's water resources have been under increasing threat of pollution in recent years due to rapid demographic changes which have coincided with the establishment of human settlements lacking appropriate sanitary infrastructure. This applies especially to peri-urban areas, which surround the larger metropolitan towns in the country, where many such settlements have developed with no proper water supply and sanitation services. People living in these areas, as well as downstream users, often utilise the contaminated surface water for drinking, recreation and irrigation, which creates a situation that poses a serous health risk to the people (Verma and Srivastava, 1990).

\section{Description of the river catchment}

The Umtata River rises in the plateau region of the Eastern Cape, approximately midway between the Drakensburg escarpment and the Indian Ocean. The catchment of the river itself is some $100 \mathrm{~km}$ long and up to $50 \mathrm{~km}$ in width. The main tributary of the Umtata River is the Ngqungqu River that enters the main river on the right bank about $27 \mathrm{~km}$ from the coast. The catchment is generally undulating, hilly and broken towards the coast with a steep

\footnotetext{
* To whom all correspondence should be addressed.

西(040) 602-2094; fax: (040) 60 2-2094; e-mail: OFatoki@ufh.ac.za

Received 21 September 2000; accepted in revised form 18 June 2001.
}

escarpment in the headwaters. In the vicinity of Umtata, the river flows through a wide plain with a flat gradient. Further downstream, the river is incised in a deep gorge. The geology of the catchment is constituted by mudstones and sandstones of the Beaufort group from the headwaters to about $30 \mathrm{~km}$ from the coast, and thence, by shales, mudstones and sandstones of the Ecca group, with exposures of dolerite intrusions mostly in the higher lying areas. There are scattered deposits of alluvium in some valleys. Soils in the catchment are moderate to deep and vary between sandy loam in the upper half to clayey loam in the downstream half. There are extensive plantations in the headwaters (DWAF, 1998).

The quality of water in the Umtata River has given cause for concern and data have always been very scanty. However, the deterioration in water quality in the middle and lower reaches of the river has given rise to concerns that water supplied from the river will be unfit for domestic use or that water treatment will have to become more sophisticated and more expensive. Of particular concern is the health of the communities along the banks of the river that depend on it primarily for their domestic water supply.

\section{Background to the study}

Generally, the major uses of water are domestic water supply, agriculture, industrial, recreation and aquatic life. The major uses of water from the Umtata River are mainly domestic and recreational. The main land use activity in the area is agricultural including livestock farming and the use of water from the river to feed livestock is common. Many uses are restricted within narrow ranges of water quality (Hammer, 1975).

South Africa can be described as a water-scarce country and with the growth in population and development there has been a large increase in municipal and industrial pollution of water. Such pollution and its related environmental impacts have remained largely unmeasured and ignored in many poor communities. For most developing communities, there is very little treatment of municipal or industrial wastewater. Where there is sufficient water to adequately dilute the pollution, the rivers may carry out natural 
remediation. Often this is not enough and also, the danger is that in a situation where water pollution may be steadily increasing, unless an effort is made to build up records and understanding of the processes and trends, the changeover from tolerable conditions may come as a sudden event. Unless controlling authorities understand the local water quality processes and are monitoring how pollution trends are developing, the associated problems may arrive too suddenly for remedial action to be implemented timeously. If pollution is allowed to grow unchecked, the result may be sudden loss of aquatic ecosystems and a profound effect on downstream users, some of whom may be primary users of the water (DFID, 1999). This study investigates water quality trends and identifies the major sources of pollution in the Umtata River.

\section{Physico-chemical and microbiological water quality properties}

There is increasingly the need for the protection of the quality of South Africa's water resources from degradation due to pollution, which interferes with the water uses at any scale. The major proportion of all water quality degradation worldwide is due to anthropogenic causes (Faniran et al., 1994). Pollution may result from point- and diffuse (non-point) sources. In less industrialised areas of South Africa like the Umtata catchment, pollution from human settlements lacking appropriate sanitary infrastructure, partially treated or untreated wastewater, leachates from refuse dumps and from land-use activities such as agriculture, are the major pollution sources to the surface water. Microbes, inorganic ions such as salts, nutrients and heavy metals are major pollutants from these sources and are identified as priority pollutants to be monitored in the river catchment.

Also, an area subject to high erosion like the Umtata catchment may have a turbidity problem. The geology of the catchment may influence the mineral contents of the river due to salts that are leached from the soil and geological formulation by infiltrating rainfall, which finds its way into the streams in the area (Du Preez and Jonas, 1983).

High turbidity, apart from seriously detracting from aesthetic characteristics of water, may render the water unsuitable for domestic, industrial, agricultural and recreational uses. Excessive turbidity in water can cause water purification problems with processes such as flocculation and filtration. When highly turbid waters are chlorinated there may also be a tendency to increase in trihalomethane (THM) precursors. Elevated turbidities are often associated with the possibility of microbiological contamination, as high turbidity makes it difficult to disinfect water properly (Van Loon, 1982; Quality of Domestic Water Supplies, 1998).

Testing water for chloride, nitrate and phosphate is important because they too can serve as pollution indicators. A high chloride concentration imparts a brackish salty taste to water and is discouraged because of health hazards. The WHO limit for chloride is $200 \mathrm{mg} \mathrm{Cl}^{-} / \ell$ (WHO, 1979). The South African Target Water Quality Range is 0 to $100 \mathrm{mg} / \ell$ (DWAF, 1996a).

Significant nitrate contamination of drinking water is found in areas of high population pressure and agricultural development. The potential health risk of nitrate in water has led to increased stringency in nitrate monitoring of waters because it can be reduced to nitrite, which has been linked to the conditions known as methaemoglobinemia in infants and pregnant women (Bush and Mayer, 1982; Canter, 1987). Owing to toxicity, the nitrate content of drinking water is regulated by European Union Directive 80/778/EEC, which states a maximum admissible concentration (MAC) of $50 \mathrm{mg} \mathrm{NO}_{3}^{-1 \ell}$. The EPA, based on the WHO guideline, adopted an MAC of $45 \mathrm{mg} \mathrm{NO}_{3}^{-} / \ell$. The WHO also states a guideline of $10 \mathrm{mg} \mathrm{NO}_{3}^{-}$as $\mathrm{N} / \ell$ in drinking water as a safe limit for babies (Council Directive 80/778/EC, 1980; WHO, 1984). High nitrate levels also stimulate algal growth (Fried, 1991; WRC, 2000) and play a role in eutrophication.

Phosphates are equally undesirable anions in water. Though they normally do not pose a health threat in domestic water, they are the limiting factor in eutrophication and result in adverse ecological effects that could render the water unsuitable for other uses (DWAF, 1986; WRC, 2000).

The existence of heavy metals in aquatic environments has led to much concern over their influence on plant and animal life in these environments and indeed on man's need for wholesome water (Stephen, 1988). The accumulation of these elements, many of which are highly toxic, can have direct consequences for man and animal life in the aquatic ecosystem. Interest in metals like Fe, $\mathrm{Mn}, \mathrm{Zn}$ and $\mathrm{Cu}$ which are required for metabolic activity in organisms lies in the "narrow window" between their essentiality and toxicity (Skidmore, 1964; Spear, 1981). Others like Pb, Cd and $\mathrm{Hg}$ exhibit extreme toxicity even at trace levels and they have bioaccumulation effects, thus necessitating their regular monitoring. The concentration of $\mathrm{Cd}$ in unpolluted water is usually less than $0.001 \mathrm{mg} / \ell$. Chronic health effects of Cd include kidney damage and pain in the bones (itai-itai disease) (Kjellstroem, 1986; Stoepller, 1991). Chronic effects of $\mathrm{Pb}$ include neurological disorders especially in children, infants and pregnant women.

Major factors affecting microbiological quality of surface waters are discharges from sewage works and runoff from informal settlements. Indicator organisms are commonly used to assess the microbiological quality of surface waters and faecal coliforms (FC) are the most commonly used bacterial indicator of faecal pollution (DWAF, 1996a; Quality of Domestic Water Supplies, 1998). They are found in water that is contaminated with faecal wastes of human and animal origin. Total coliforms (TC) comprise bacterial species of faecal origin as well as other bacterial groups (e.g. bacteria commonly occurring in soil). The coliforms are indicative of the general hygienic quality of the water and potential risk of infectious diseases from water. High FC and TC counts in water are usually manifested in the form of diarrhoea and sometimes by fever and other secondary complications. In this study, a situation analysis was performed for water quality in the Umtata River.

\section{Materials and methods}

\section{Sampling sites}

The location of the 10 selected sites along the Umtata River is shown in Fig 1. The sampling sites were chosen to reflect different activities in the catchment - upstream, midstream and downstream which may affect the quality situation in the river.

Sites S1 (as the source of the river was not accessible, S1 which was the closet accessible site to the source was chosen as the reference) and $\mathrm{S} 2$ were upstream. $\mathrm{S} 1$ was supposed to be pristine. However, there are three plantation locations located upstream of this site which impacts on river quality. S2 was downstream of Tabase location (another informal settlement). This site was chosen to monitor the impact of the informal settlement on the river. Sites $\mathrm{S} 3$ to S5 are midstream along the river. S3 was upstream of the dam and has an impact from Kanbi informal settlement located near the bank. S4 and S5 are the Umtata Dam and downstream of the dam, respectively. Water from Umtata Dam is treated and supplied to most of Umtata. These sites were chosen so as to ascertain the 


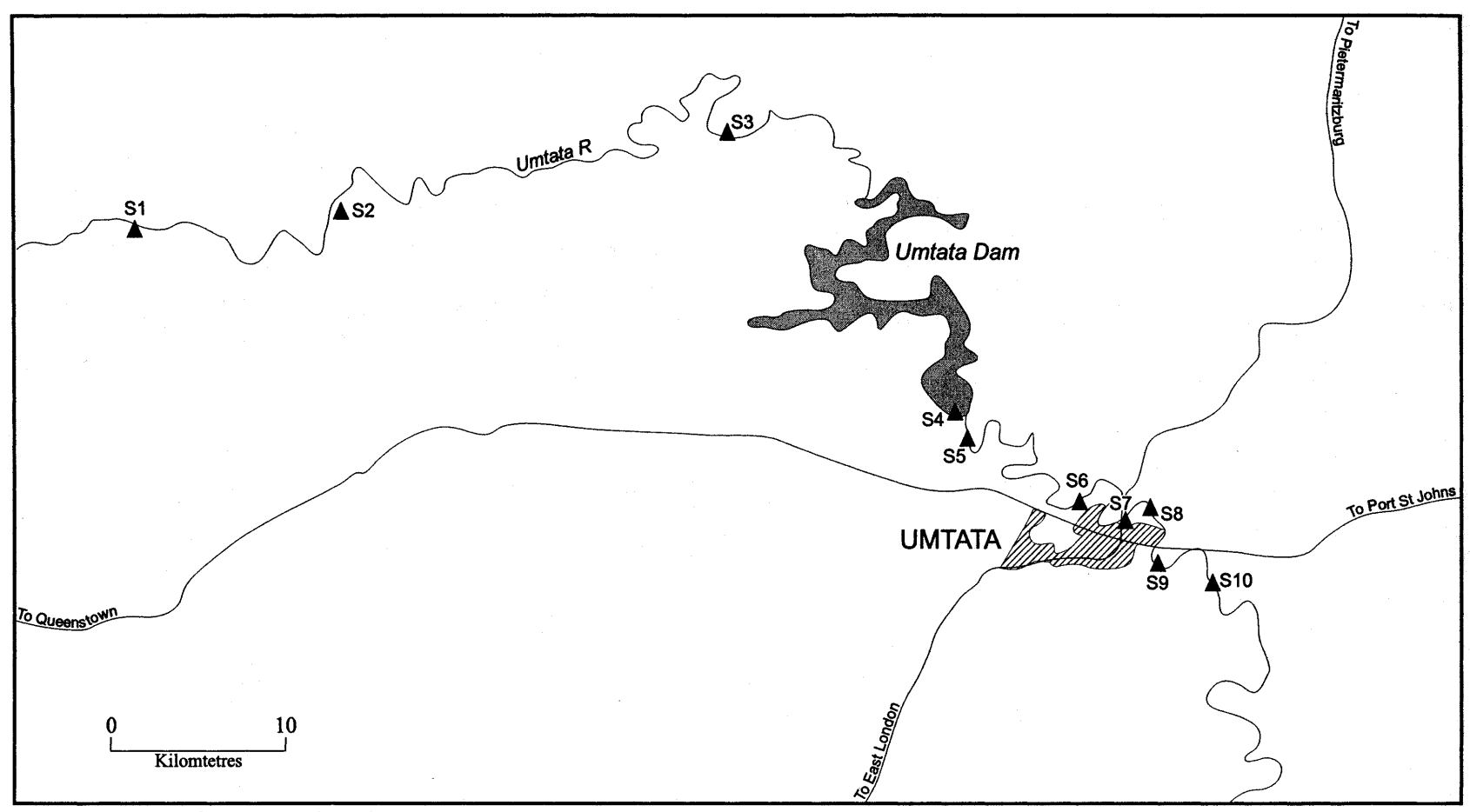

Figure 1

Map of the sampling sites

quality of the water from the dam (S4) and to note any change in quality downstream of the dam (S5). Sites S6 to S10 are downstream. S6 is downstream of the Pola Park location (a peri-urban settlement in Umtata town). This site was chosen to establish the effect of runoff from this settlement on the river quality. S7 is at Norwood Bridge, downstream of the Umtata City centre. There is also a rubbish dump upstream of the site. The urban runoff and leachates from the rubbish dump discharging into the river would adversely affect its quality at this site and these were monitored at this site. Site S8 was a site downstream of the Umtata Sewage Works effluent discharge point. The impact of the sewage discharge on the river was monitored at this site. Site $\mathrm{S} 9$ is at Tipini location. This is another peri-urban settlement located on the riverbank. Here, there is also a large rubbish dump full of carcasses and human faeces (public defecation is a common practice at this site). It is worth mentioning that all the informal settlements are located on steep slopes close to the river which could greatly increase their pollution impact on the river. Site S10 is at the First Fall further down the river. Samples were taken between May 1999 and April 2000 to cover the four seasons of the year so as to check for seasonal variations in water quality.

Before sampling for chemical analyses, sample bottles were cleaned by soaking in detergent for $24 \mathrm{~h}$, followed by rinsing several times with tap water until free of detergent, rinsed with $5 \%$ nitric acid and then thoroughly with distilled-deionised water (DWAF, 1992; Quality of Domestic Water Supplies, 1999). Sample bottles were cleaned and sterilised according to the standard procedures for microbiological analysis (DWAF, 1992). Samples for chemical and microbiological analyses were collected according to the standard procedures described in the sampling guide (DWAF, 1992; Quality of Domestic Water Supplies, 1999). Samples for trace metal analyses were preserved with $5 \mathrm{~m} \ell$ conc. $\mathrm{HNO}_{3}$. After collection the samples were placed in cooler boxes with ice chests while being transported to the laboratory and kept at about $4^{\circ} \mathrm{C}$ until analysed. Most samples including all microbiological analyses were analysed within $24 \mathrm{~h}$. All chemical analyses were done at least in duplicate. The quality assurance studies were done in triplicate for each parameter.

\section{Physico-chemical analyses}

Temperature and $\mathrm{pH}$ were determined on-site with a $\mathrm{pH} 330$ meter supplied by Merck NT Laboratory Pty Ltd. Conductivity and TDS were also determined on-site with the LF 330 conductivity meter also supplied by Merck NT Pty Ltd. Turbidity was determined using the HI 93703 microprocessor turbidity meter (Hanna Instruments). Nitrate, phosphates and sulphates were determined with the Nova 60 Water Analyser supplied by Merck NT Pty Ltd. Chloride was determined using the standard argentometric method. Total hardness was determined by standard EDTA titration (Basset et al., 1978; Van Loon, 1982). Metals were determined by standard spectrometric methods (Fries and Getrost, 1977; DWAF, 1992). Distilled deionised water was substituted for test solution when running blanks for the chemical parameters measured. For quality control, water samples were spiked with known amounts of $\mathrm{KNO}_{3}$, $\mathrm{NaH}_{2} \mathrm{PO}_{4}, \mathrm{ZnSO} 4.7 \mathrm{H}_{2} \mathrm{O}, \mathrm{PbNO}_{3}, \mathrm{Cd}\left(\mathrm{NO}_{3}\right)_{2}$, respectively and the recovery of nitrate, phosphates, $\mathrm{Zn}, \mathrm{Cd}$, and $\mathrm{Pb}$ were measured using the standard procedures described above for the parameters (Fries and Getrost, 1977; DWAF, 1992).

\section{Microbiological analyses}

Faecal and total coliforms counts were performed using the standard membrane filtration method. The $\mathrm{mFC}$ and $\mathrm{m}$-Endo agars were used for faecal coliform and total coliform counts respectively. Both media were purchased from Merck NT Laboratry supplies. The $100 \mathrm{~m} \ell$ water sample was filtered using $0.45 \mu \mathrm{m}$ pore size, $47 \mathrm{~mm}$ diameter filter membrane. M-Endo plates were incubated at $35^{\circ} \mathrm{C}$ for $24 \mathrm{~h}$ while $\mathrm{mFC}$ plates were incubated at $44.5^{\circ} \mathrm{C}$ for $24 \mathrm{~h}$ (DWAF, 1992). 

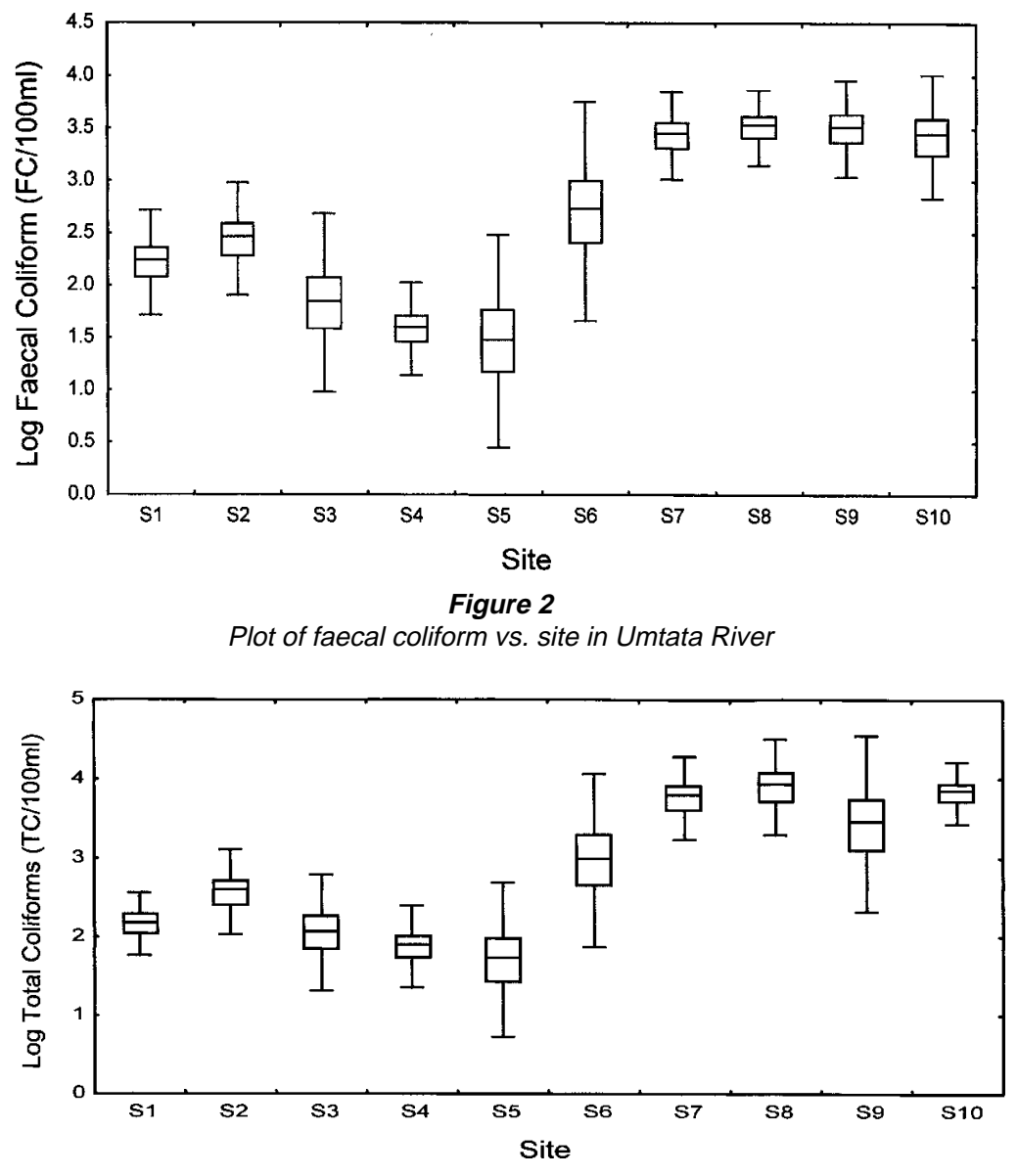

Figure 3

Plot of total coliform vs. site in Umtata River

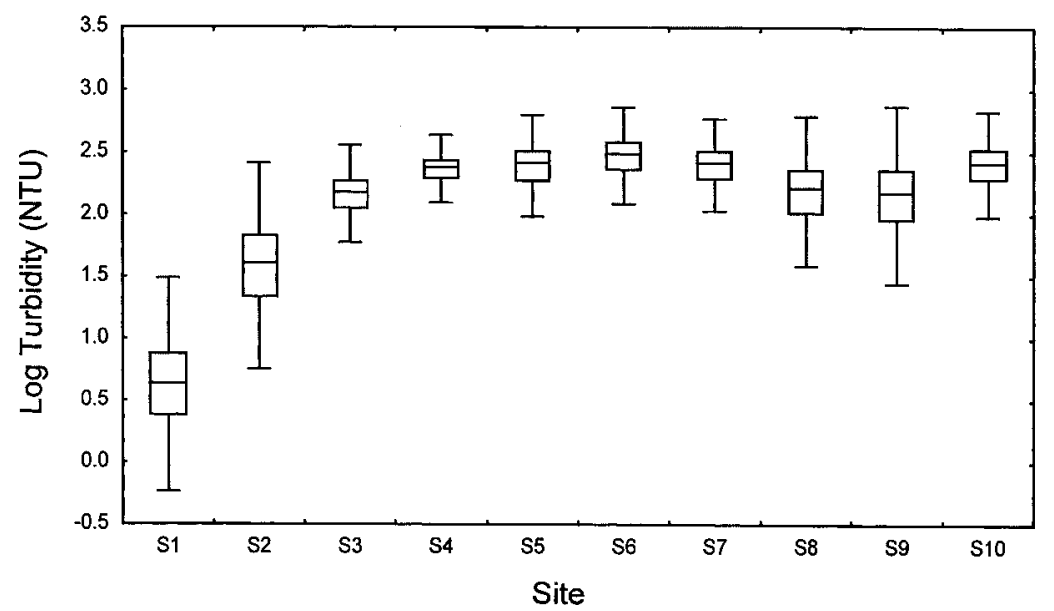

Figure 4

Plot of turbidity vs. site in Umtata River

\section{Results and discussion}

The percentage recoveries obtained for the representative anions and cations are, $\mathrm{NO}_{3}^{-}, 90 \pm 6 \%, \mathrm{PO}_{4}^{3-}, 85 \pm 6 \%, \mathrm{Cd}, 74 \pm 5 \%, \mathrm{~Pb}, 85 \pm 6 \%, \mathrm{Zn}, 77 \pm 7 \%$ and $\mathrm{Mn}, 93 \pm 3 \%$ which validated the experimental procedures used for the chemical analyses.

The results of water quality studies are presented in Figs. 2 to 7 for parameters of concern. Other parameters like $\mathrm{pH}$, conductivity, TDS, $\mathrm{Cl}^{-}, \mathrm{SO}_{4}^{2-}$ and total hardness are within acceptable limits (DWAF, 1996a).

The results of the analyses for most parameters did show some expected trends in water quality from upstream to downstream sites on the river along the 10 sampling sites. Generally, the concentrations of most of the parameters downstream are higher than at midstream or upstream. Also the phosphate concentrations in the river are highest at Site 8, which was expected, as it is downstream of the sewage works effluent discharge point and eutrophication is most pronounced in the river water at this site (Fig. 6). Some seasonal variations are indicated. For instance, water summer months temperatures are higher than winter months and the concentrations of most parameters (e.g. coliforms, turbidity, nitrates conductivity, TDS and chloride) are higher in the summer months than in the winter months, showing increased contributions from runoff from the settlements during the summer rains.

Using the guidelines for domestic water supply (Quality of Domestic Water Supplies, 1998), the overall class of water quality in the river for all the sites is 5 - purple (i.e. completely unacceptable totally unsuitable for use without treatment). This indicates that the water is not fit for domestic use and may pose a serious health risk to communities along the river-bank who rely on it for primary domestic use.

The faecal- and total coliforms, turbidity, nutrients and cd levels are the major problems in the river (Figs. 2 to 7). Some other metals have values that exceed the acceptable limits (e.g. $\mathrm{Pb}$, $\mathrm{Fe}$, and $\mathrm{Mn}$ ). These are, however, not significant.

\section{Micro-organisms}

The levels of indicator organisms in the river are shown in Figs. 2 and 3 for the different sites. High levels of coliforms were found at all sites. Based on the South African guideline value of 0 counts $/ 100 \mathrm{~m} \ell$ faecal and 10 counts $/ 100 \mathrm{~m} \ell$ total coliforms (DWAF, 1996a; Quality of Domestic Water Supplies, 1998), the water from the river is not suitable for direct domestic use and may pose a health risk to the river-bank communities. The faecal coliform levels also did not fall within the guideline value of 0 to 130 counts $/ 100 \mathrm{~m} \ell$ set for full-contact recreation (DWAF, 1996b). At this level there is a risk of contracting gastrointestinal illness as a result of full-contact recreation or direct consumption of untreated water (DWAF $1996 \mathrm{a}$ and b).

The faecal coliform values in the river at most sites are also higher than the South African guideline of 200 counts $/ 100 \mathrm{~m} \ell$ for water used for livestock watering (DWAF, 1996c) and its use to feed livestock in the catchment could pose a significant health risk to animals.

A definite increase in coliforms was observed from Sites S6 to S10 due probably to contributions from peri-urban- and urban runoffs from informal 
settlements and the city centre, respectively, along the river course (S6, S7 and S9) and from effluent discharge from the main Umtata Sewage Works (S8).

The majority of the people in the catchment belong to the poor socio-economic class and they lack proper sanitation. Public defecation is a common practice, especially around Tipini location (average level of faecal coliform was highest at Tipini location, which was expected because there was a large refuse dump full of carcasses of dead animals and human faeces, at this site, which may be washed into the river during rains). Contamination of the river by domestic animals is an added factor at some of the sites (e.g. S2 and S3) as it is common to see animals drinking from the same river source that people use for their domestic water supplies (S2).

\section{Turbidity}

Turbidity values are shown in Fig. 4. None of the sites sampled met the South African guideline of 0.1 NTU for turbidities in water for domestic use (Quality of Domestic Water Supplies, 1998). This disqualifies the river for direct domestic use. The high turbidity also makes the sight of the river water unpleasant for full-contact recreation (DWAF, 1996b). The high turbidity observed for all the sites (NTU increases from upstream to downstream) is due to known high donga erosion in the catchment, due possibly to the nature of the soil and the increased runoff from the settlements.

The values of turbidity obtained in this study were much higher than those reported for Isinuka River (spring average, 43.03 NTU and summer average, 0.6 NTU for summer) by (Faniran et al., 2001).

\section{Nutrients}

Nutrient levels are equally high in the river (Figs. 5 and 6). The WHO and South African safe limit for nitrate in domestic water for lifetime use is $10 \mathrm{mg} / \mathrm{l}$ as N (WHO, 1984; Quality of Domestic Water $\widehat{\overline{\mathrm{\sigma}}}$ Supplies, 1998). This nitrate level is exceeded at some sites (Fig. 5) and would make the river water 8 unsuitable for direct domestic use at these sites as this may expose infants and pregnant women to the risk of methaemoglobinemia (Bush and Mayer, 1982; Canter, 1987).

The phosphate level was highest at Site S8 (Fig. 6). The South African guideline for P in water systems that will reduce the likelihood of algal and other plant growth is $5 \mu \mathrm{g} / \ell$ (DWAF, 1996d). Other workers have reported that eutrophication-related problems in temperate zones aquatic systems begin to increase at ambient total $P$ concentrations exceeding $0.035 \mathrm{mg} \mathrm{P} / \ell$. The value is higher for warm-water systems - of the order of 0.34 to $0.70 \mathrm{mg} P / \ell$ (Rast and Thornton, 1996). The associated $\mathrm{N}$ concentration would be of the order of 0.34 to $0.70 \mathrm{mg} \mathrm{N} / \ell$. It is accepted that these represent nutrient threshold levels, beyond which there will be a corresponding increase

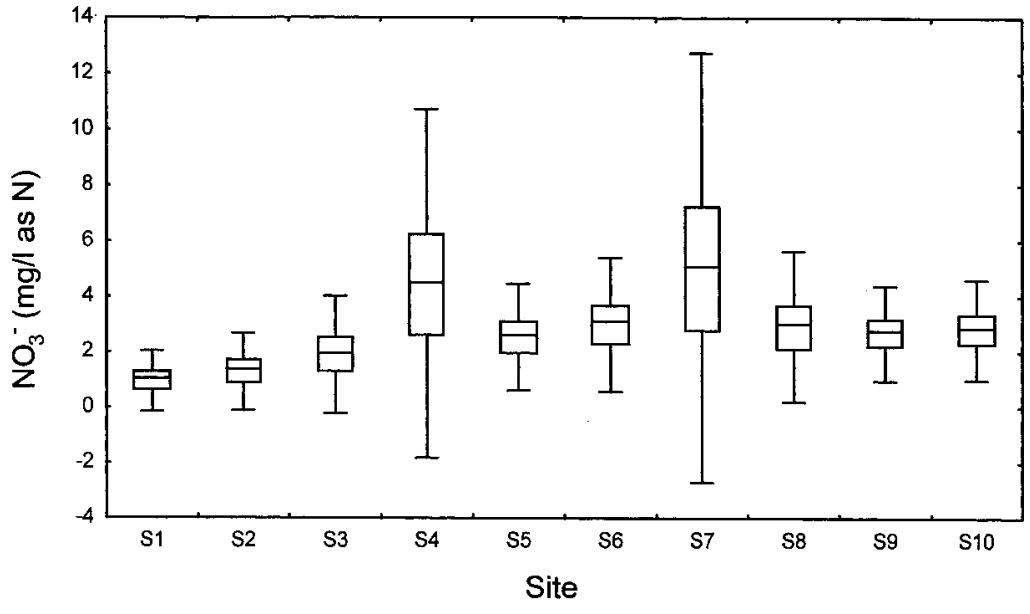

Figure 5

Plot of nitrate vs. site in Umtata River

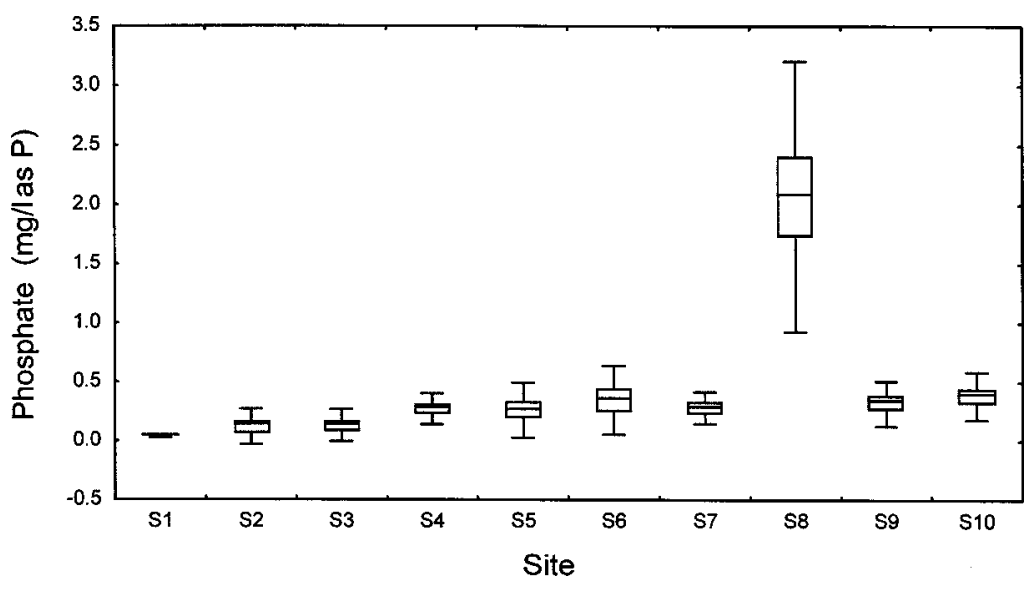

Figure 6

Plot of phosphate vs. site in Umtata River

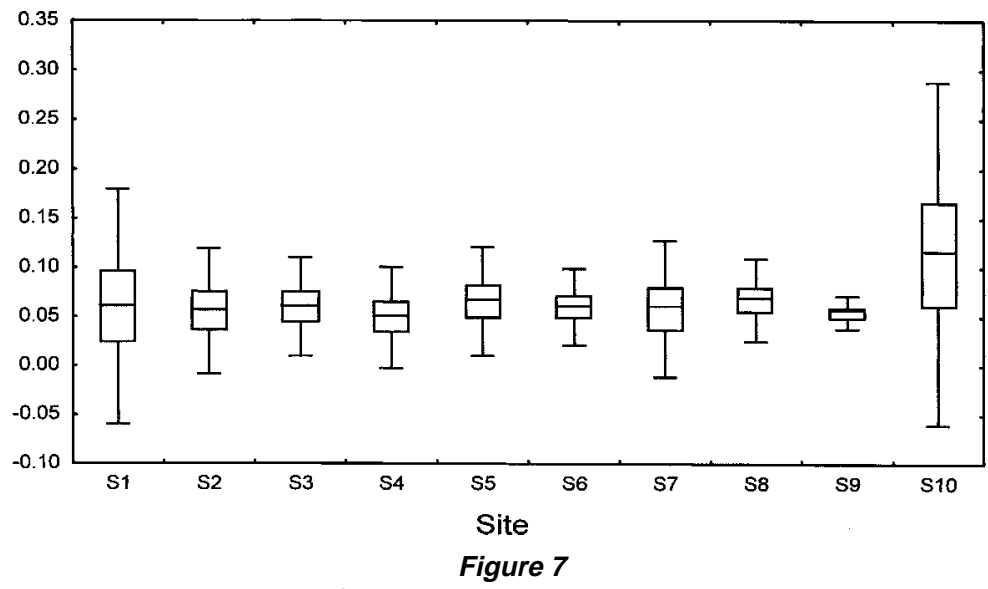

Plot of cadmium vs. site in Umtata River

in the risk and intensity of plant-related water quality problems (OECD, 1982). These threshold values for nutrients (Rast and Thornton, 1996) are exceeded in the river and eutrophication is well pronounced in the river. The incidence of eutrophication could adversely affect the use of the river for recreation as the covering of large areas by macrophytes could prevent access to waterways and could cause unsightly and malodorous scum which could make recreation unpleasant (Murray et al., 2000). Also, eutrophication could lead to the growth 
of blue-green algae, which could release toxic substances (cyanotoxins) into the water. Cyanotoxins are recognised to have caused the death of farm livestock (Holdsworth, 1991). This phenomenon, which could occur in the river because of its high nutrient level, could also pose a health risk to livestock when the river water is used to feed livestock.

The high nutrient levels may be due to diffuse sources from settlements and agricultural runoffs and to point discharge from Umtata Sewage Works. The abnormally high level of phosphate at S8 (Fig. 6) supported the view that the treatment efficiency of the city's major sewage works is poor and that the sewage effluent is a major source of pollution of the river.

The nitrate levels in Umtata River are also much higher than those reported for Isinuka River by Faniran et al. (summer average, $0.5 \mathrm{mgNO}_{3}-\mathrm{N} / \ell$ ) (Faniran et al., 2001). However, the water quality situation in the Umtata River compares favourably with that reported for the Buffalo River where nutrients and faecal contamination were listed among the variables of concern (WRC, 1996). Urban effluents from the sewage treatment works and diffuse runoff from urban catchments were said to be the source of phosphate in the Buffalo River while the source of faecal bacteria was attributed to raw sewage (WRC, 1996).

\section{Cadmium}

Trace metal concentrations in the river, expectedly, are generally low for most of the metal ions (especially for domestic use of the river water), as the area is not highly industrialised. However, the Cd levels shown in Fig. 7 are quite high at all the sites and are above the South African guideline limit of $0.005 \mathrm{mg} \mathrm{Cd} / \ell$ in water for domestic use (DWAF, 1996a; Quality of Domestic Water Supplies, 1998). The metal concentrations do not show any particular trend and this indicated that the source of the metal might be diffuse. The probable source of cd is from natural sources due to the geological formation of the catchment soil and from runoff from agricultural soils where phosphate fertilisers have been applied (cadmium is a common impurity in phosphate fertilisers) (Stoeppler, 1991) and is exacerbated by the high turbidity levels. Other probable sources include leachates from disused ni-cd based batteries and cadmiumplated items (Hutton et. al. 1987; Stoeppler, 1991) from the rural communities that are disposed in the refuse dumps in the settlements (the leachates from these dumps can easily be washed into the river by rain).

In view of the fact that the major uses of water in the catchment are domestic and recreational, the high levels of coliforms and cadmium in the river are of great concern. The high coliform levels might expose the primary users of water from the river (especially children) to high risk of water-related diseases like diarrhoea. Cadmium is extremely toxic and the primary use of water high in cadmium could cause adverse health effects to consumers (Quality of Domestic Water Supplies, 1998). The use of water from the river for livestock watering may also expose the livestock to chronic cadmium metal poisoning.

Water from Umtata River is abstracted (Umtata Dam) and treated to supply most of Umtata. The results of water quality in treated water samples from Umtata showed that the faecal- (range, 0 to $20 / 100 \mathrm{~m} \ell$ ) and total coliform counts (range, 2 to $10 / 100 \mathrm{~m} \ell$ ) in some of the samples exceed the acceptable limits of coliforms in water for domestic use (Quality of Domestic Water Supplies, 1998). Using this guideline, the overall class of the tap water quality in Umtata is 3 (that is, marginally good). Given that these parameters are among the major problems in the river, this shows that these problems are not totally removed by the current treatment procedures, which need to be looked into.

The microbiological quality of domestic water sources is of great importance and should not be compromised.

\section{Conclusion}

The Umtata River has been characterised in terms of its physicochemical and microbiological quality properties. The results have indicated gross pollution of the river, especially as regards microbes and cadmium metal. This poses a health risk to several rural communities along the banks of the river who rely on it primarily for their domestic source. The gross pollution of the river is negatively affecting the water purification systems in Umtata, which may increase the cost of treating the water to potable standards.

\section{Acknowledgement}

The authors wish to thank the WRC for funding this research.

\section{References}

BASSETT J, DENNY RC, JEFFERY GH and MENDHAM J (1978) Vogel's Textbook of Quantitative Inorganic Analyses (4th edn.) Longman Group Limited, London.

BUSH D and MEYER M (1982) A case of infantile methemoglobinemia in South Dakota. J. Environ. Health 44310 - 311.

CHAPMAND (1996) Water Quality Assessments (2nd edn.). Publ.E \& FN Spon, London.

CANTER LW (1987) Nitrate and pesticides in ground water: An analysis of a computer-based literature search. In: Fairchild-Lewis DM (eds.) Ground Water Quantity and Agricultural Practices. Chelsea, MI.

COUNCIL DIRECTIVE 80/778/EEC (1980). Off. Pub. Env. Commun. Brussels $22911-29$.

DFID (1999) A Simple Methodology for Water Quality Monitoring. Report OD 142 (KAR Project R6662). Pearce GR, Chandhry MR and Ghulam S (eds.). Department for International Development.

DWAF (1986) Management of Water Resources of the Republic of South Africa. Department of Water Affairs \& Forestry, Pretoria.

DWAF (1992) Analytical Methods Manual, TR 151. Department of Water Affairs \& Forestry, Pretoria.

DWAF (1996a) South African Water Quality Guidelines. 1: Domestic Uses (2nd edn.). Department of Water Affairs \& Forestry, Pretoria.

DWAF (1996b) South African Water Quality Guidelines. 2: Recreational Water Use (2nd edn.). Department of Water Affairs \& Forestry, Pretoria.

DWAF (1996c) South African Water Quality Guidelines. 5: Agricultural Use: Livestock Watering. Department of Water Affairs \& Forestry, Pretoria.

DWAF (1996d) South African Water Quality Guidelines. 7: Aquatic Ecosystems (1st edn.). Department of Water Affairs \& Forestry, Pretoria.

DWAF (1998) Umtata River Catchment Preliminary Framework for the Development of an Integrated Catchment Management Plan. Report by Ninham Shand Consulting Engineers. Department of Water Affairs \& Forestry, Pretoria.

DU PREEZ AL and JONAS PMM (1983) Chemical Composition of Transkei River and Dam Water. Department of Chemistry, Univ. of Transkei.

FANIRAN JA, ADELEKE, BB and ODERINDE, RA (1994) Forcados Terminal Integrated Projects: Baseline Ecological Studies. Commissioned by Shell Petroleum Development Company of Nigeria.

FANIRAN JA, NGCEBA FS, BHAT RB and OCHE CY (2001) An assessment of the water quality of the Isinuka springs in the Transkei region of Eastern Cape, Republic of South Africa. Water SA 27 (2) 241-250.

FRIED JJ (1991) Nitrate and control in the EEC aquatic environment. In: Borgadi I and Kuzelka D (eds.) Nitrate Contamination, Exposure, 
Consequences and Control. NATO ASI Series, G 30, Ecological Studies. $55-63$.

FRIES J and GETROST H (1977) Organic Reagents for Trace Analysis. E. Merck Darmstadt.

HAMMER MJ (1975) Water and Waste-Water Technology. John Wiley \& Sons, Inc.

HUTON M, CHANEY RL, KRISHNA CR, MURTI M, OLADE, A and PAGE AL (1987) Group report: Cadmium. In: Hutchinson TC and Meema KM (eds.) Lead, Mercury, Cadmium and Arsenic in the Environment. John Wiley, New York. 35-41.

HOLDSWORTH R (ed.) (1991) New Health Consideration in Water Treatment. Avebury Technical, Aldershot.

KJELLSTROEM T (1986) Itai-itai disease. In: Friberg L, Elinder CG, Kjellstroem T and Norberg GF (eds.) Cadmium and Health, A Toxicological and Epidemiological Appraisal II: Effects and Response. CRC Press, Boca Raton, Florida. 257-290.

MURRAY K, DUPREEZ M and VAN GINKEL C (eds.) National Eutrophication Monitoring Programme. Implementation Manual Draft. Water Research Commission (Draft Report).

OECD (1982) Eutrophication of Waters: Monitoring, Assessment and Control. Technical Report. Organization for Economic Development, Paris.

PACKHAM RF (1983) Water Quality and Health. In: RM Harrison (ed.) Pollution: Causes Effects and Control. Royal Society of Chemistry, London.

QUALITY OFDOMESTIC WATER SUPPLIES (1998)Assessment Guide. 1 (2nd edn.). Department of Water Affairs \& Forestry, Department of Health and Water Research Commission.

QUALITY OF DOMESTIC WATER SUPPLIES (1999) Sampling Guide 2. Department of Water Affairs and Forestry, Department of Health and Water Research Commission.
RAST W and JA THORNTON (1996) Trends in eutrophication research and control. Hydrol. Processes 10295 - 313

SKIDMORE JF (1964) Toxicity of zinc compounds to aquatic animals with special reference to fish. Q. Rev. Biol. $39227-248$.

SPEAR PA(1981)Zinc in the Aquatic Environment: Chemistry, Distribution and Toxicology. National Research Council of Canada, Associate Committee on Scientific Criteria for Environmental Quality. Report NRCC No. 17585. Ottawa.

STEPHEN WI (1988) Zinc, cadmium, mercury and lead. In: West TS and Nurnberg HW (eds.) The Determination of Trace Metals in Natural Waters. Blackwell Scientific Publications. Oxford.

STOEPPLER M (1991) Cadmium. In: Merian E (ed.) Metals and Their Compounds in the Environment: Occurrence, Analysis and Biological Relevance. VCH, New York. $803-851$.

VERMA BL and SRIVASTAVA RN (1990) Measurement of the personal cost of illness due to some major water-related issues in an Indian rural population. Int. J. Epidemiol. 19169 - 176.

VAN LOON JC (1982) Chemical Analysis of Inorganic Constituent of Water. CRC Press.

WHO (1979) Sodium Chloride and Conductivity in Drinking Water. World Health Organization, Copenhagen.

WHO (1984) Guidelines for Drinking Water Quality. World Health Organization, Geneva.

WRC (1996) A Situation Analysis of Water Quality in the Catchment of the Buffalo River, Eastern Cape, with Special Emphasis on the Impacts of Low Cost, High-Density Urban Development on Water Quality. O'Keeffe JH, Van Ginkel CE, Hughes DA, Hill TR and Aston PJ (eds.) WRC Report No 405/1/96.

WRC (2000) National Eutrophication Monitoring Programme. Implementation Manual. 
